\title{
OPTIMALISASI PENERIMAAN NEGARA DARI CUKAI MINUMAN MENGANDUNG ETIL ALKOHOL: ANALISIS DATA MIKRO
}

\author{
Mohtar Rasyid \\ Universitas Trunojoyo Madura \\ Alamat Korespondensi: mohtar.rasyid@gmail.com
}

\begin{abstract}
This study aims to evaluate the potential government revenue from alcoholic baverages (MMEA) excise. To measure the potential revenue from MMEA, this study uses a micro consumption database of household consumption for MMEA published by the Central Statistics Agency (BPS) in the SUSENAS. Data on consumption of MMEA is converted in standard units (liters) and multiplied by the new excise tax rate. The estimation results of excise receipts from MMEA indicate that the magnitude of the potential for excise duty can reach around IDR 9 Trillion. While the actual state revenue from MMEA excise is still in the range of IDR 5 to 6 Trillion. This finding indicates that Indonesia's current MMEA excise tax revenue is relatively unoptimal. Some major suggestions conveyed in this study are:(a) the need to increase enforcement efforts so that excise violations can be minimized; and (b) the need to introduce traditional MMEA into the MMEA excise scheme so that the excise control function for alcoholic drinks can be further improved.
\end{abstract}

KATA KUNCI:

MMEA, tarif cukai, konsumsi alkohol, penerimaan negara, data mikro

\begin{abstract}
ABSTRAK
Penelitian ini bertujuan untuk mengevaluasi potensi penerimaan cukai Minuman Mengandung Etil Alkohol (MMEA). Untuk mengukur potensi penerimaan cukai, penelitian ini menggunakan basis data mikro konsumsi rumah tangga untuk minuman beralkohol yang dipublikasikan oleh Badan Pusat Statistik (BPS) dalam SUSENAS. Data konsumsi minuman beralkohol dikonversi dalam satuan standar (liter) dan dikalikan dengan tarif cukai yang baru. Hasil estimasi penerimaan cukai dari MMEA menunjukkan bahwa besarnya potensi cukai bisa mencapai kisaran Rp 9 Triliun. Sementara penerimaan negara aktual dari cukai MMEA masih berkisar antara Rp 5 sampai 6 Triliun. Temuan ini mengindikasikan bahwa penerimaan cukai MMEA di Indonesia saat ini relatif masih belum optimal. Beberapa saran disampaikan dalam penelitian ini antara lain, perlunya upaya untuk meningkatkan upaya penegakan aturan agar pelanggaran cukai dapat ditekan. Selain itu, perlu upaya untuk memasukkan MMEA tradisional ke dalam skema cukai MMEA agar fungsi pengendalian cukai untuk minuman beralkohol dapat lebih ditingkatkan.
\end{abstract}

\section{KLASIFIKASI JEL:}

$\mathrm{H} 23, \mathrm{H} 30$

CARA MENGUTIP:

Rasyid, M. (2020). Optimalisasi penerimaan negara dari cukai minuman mengandung etil alkohol: analisis data mikro. Indonesian Treasury Review: Jurnal Perbendaharaan, Keuangan Negara dan Kebijakan Publik, 5(2), 131-141. 


\section{PENDAHULUAN}

\subsection{Latar Belakang}

Akhir-akhir ini media tanah air sering mewartakan kasus kematian akibat minuman keras yang dioplos dengan racikan bahan berbahaya. Banyak pihak yang menilai bahwa kasus ini terjadi akibat perilaku negatif masingmasing individu. Bagaimanapun, kasus kematian akibat minuman keras masih akan terus terjadi jika pemerintah tidak melakukan regulasi yang tepat untuk mengantisipasi efek negatif minuman keras. Dalam konteks ekonomi, minuman keras (mengandung alkohol) ini termasuk dalam salah satu sin commodities (Chen, Chen, Liu, Kuo, \& Huang, 2018, hal. 9).

Salah satu bentuk regulasi pemerintah guna membatasi dan mengawasi aktivitas produksi maupun konsumsi untuk sin commodities adalah melalui penerapan aturan cukai. Di Indonesia, hingga saat ini terdapat tiga kelompok komoditi yang dikenakan tarif cukai yakni Etil Alkohol, Minuman Mengandung Etil Alkohol (MMEA), dan rokok. Kontribusi dari cukai yang berasal dari ketiga produk tersebut sejauh ini cukup signifikan. Pada tahun 2017, dilaporkan bahwa penerimaan cukai yang berasal dari ketiga kelompok komoditas tersebut mencapai sekitar Rp 153 Triliun. Berdasarkan RAPBN 2018, penerimaan cukai diharapkan naik menjadi Rp 155 Triliun dengan komposisi: cukai rokok Rp 148,2 Triliun; cukai MMEA Rp 6,5 Triliun; cukai Etil Alkohol Rp 0,2 Triliun dan pendapatan cukai lainnya sebesar Rp 0,5 Triliun (Direktorat Jenderal Anggaran, 2017, hal. 43). Dari segi besaran, sumbangan cukai MMEA masih relatif kecil meskipun potensinya cukup besar. Studi PSEKP UGM berbasis data mikro 2008, menyebutkan bahwa potensi penerimaan cukai MMEA sepuluh tahun yang lalu saja berkisar Rp 7 Triliun (Direktorat Jenderal Anggaran, 2017, hal. 56). Tentunya, dengan adanya kenaikan basis tarif cukai dan peningkatan konsumsi, seharusnya penerimaan cukai MMEA saat ini jauh lebih besar.

Relatif kecilnya penerimaan cukai MMEA mengindikasikan kecilnya "hukuman" negara kepada produk berbahaya ini. Sehubungan dengan potensi yang dimiliki oleh produk MMEA, maka muncul pemikiran untuk memperluas jangkauan basis pajak produk MMEA dengan penerapan cukai untuk semua jenis MMEA yang beredar di masyarakat, termasuk jenis MMEA tradisional. Tidak hanya di Indonesia, salah satu fenomena menarik dari produk ini adalah relatif besarnya produk MMEA tak tercatat atau lebih dikenal sebagai Unrecorded Alcohol. Menurut perkiraan WHO, tak kurang dari 25 persen konsumsi MMEA di dunia diperkirakan tidak tercatat (IAS, 2013, hal. 15). Ketiadaan cukai menyebabkan harga minuman keras relatif murah dan mudah untuk diakses, meskipun sejumlah himbauan bahkan penindakan oleh aparat sudah sering dilakukan. Harga yang murah mengacaukan sinyal kepada calon pembeli yang menganggap MMEA sebagai barang konsumsi biasa. Seharusnya cukai dapat menjadi piranti yang cukup efektif untuk mengendalikan konsumsi MMEA melalui pengenaan harga yang tinggi, sekaligus mendongkrak penerimaan negara.

Meskipun dipercaya penerimaan cukai MMEA dapat ditingkatkan, akan tetapi riset tentang cukai MMEA di Indonesia relatif minim sehingga pemerintah memiliki basis informasi yang terbatas untuk menentukan tarif cukai optimum. Padahal kebutuhan untuk menentukan tarif optimum saat ini sangatlah mendesak baik dari sisi optimalisasi penerimaan negara maupun untuk mengurangi secara signifikan dampak buruk minuman keras.

Untuk itulah maka penelitian ini secara khusus bertujuan untuk: (1) mengestimasi potensi cukai MMEA di Indonesia, (2) mengestimasi dampak kenaikan cukai MMEA terhadap penerimaan negara, dan (3) mengestimasi dampak cukai MMEA terhadap perilaku minuman keras di Indonesia.

Urgensi penelitian tentang cukai MMEA di Indonesia sangat relevan dikaitkan dengan sikap pemerintah yang cenderung konservatif dalam target penerimaan cukai MMEA, sementara dampak negatif MMEA hampir tiap hari kita tonton di televisi. Sekedar himbauan atau bahkan penindakan aparat hanya bersifat sporadis. Sudah saatnya perang melawan MMEA dilakukan melalui senjata yang efektif yaitu pita cukai.

\section{LANDASAN TEORI}

Sebagai salah satu komoditi yang tersedia di pasar, produk alkohol juga memiliki nilai ekonomi dievaluasi dari sudut benefit (keuntungan) dan cost (biaya)(Chandra \& Gufraeni, 2009, hal. 172). Keuntungan dari produk alkohol secara langsung dapat dihitung dari revenue yang diterima oleh produsen lokal baik yang berasal dari penjualan domestik maupun hasil dari perdagangan. Penerimaan pajak penjualan dari minuman mengandung alkohol juga relatif besar. Keuntungan dari komoditi ini juga dapat diukur dari penyerapan tenaga kerja baik dari lini produksi hingga distribusi (Hessari, Knai, Morvan, Petticrew, \& Landreat, 2018, hal. 533). Perhitungan keuntungan dari komoditi atau minuman mengandung alkohol sama saja dengan perhitungan keuntungan komoditi lain umumnya.

\subsection{Aspek Ekonomi Alkohol}

Problem utama adalah perhitungan dari sisi biaya. Hingga saat ini, terdapat ketidakpastian dan ketidaksepakatan yang cukup luas mengenai komponen apa yang harus dimasukkan sebagai biaya termasuk juga cara pengukurannya. Perbedaan persepsi terhadap cost dari minuman alkohol ini memiliki implikasi kebijakan yang berbeda (IAS, 2013, hal. 30). Dari sudut kebjakan, 
biaya dari minuman berakohol tidak hanya diukur dari efek negatif minuman berakohol terhadap konsumen namun juga dampaknya terhadap masyarakat secara luas. Fokus kebijakan seharusnya juga ditujukan untuk mengatasi problem yang tidak nampak dalam jangka pendek seperti resiko penyakit akibat minuman serta masalah lain seperti peningkatan resiko kriminalitas akibat pengaruh buruk minuman berakohol (Chisholm, Moro, Bertram, Pretorius, Gmel, Shield, \& Rehm, 2018, hal. 514).

Secara umum, komponen biaya dari konsumsi minuman mengandung alkohol yang relatif banyak disepakati antara lain adalah biaya kesehatan akibat menegak minuman berakohol, biaya kriminalitas akibat alkohol dan penurunan produktivitas akibat alkohol. Komponen biaya tersebut belum memasukkan biaya yang ditanggung akibat ketidakharmonisan hubungan dalam rumah tangga maupun hubungan antar kerabat dalam lingkup masyarakat sekitar (social network) (Gallet, 2007, hal, 133).

Selebihnya manfaat dari konsumsi alkohol lebih banyak bersifat eksternal, seperti memperoleh jaringan kelompok sosial tertentu, memperlancar hubungan dan memperkuat modal sosial. Selebihnya minuman beralkohol mungkin sedikit memiliki efek kesehatan baik secara pribadi maupun secara kelompok (Haas, Wickham, McKenna, Morimoto, \& Brown, 2018, hal. 523; Jernigan \& Waters, 2009, hal. 14).

Kenikmatan tersebut jika diukur secara komprehensif tidak sebanding dengan biaya yang akan ditimbulkan. Biaya-biaya langsung yang ditanggung secara pribadi dari peminum alkohol selain pengeluaran untuk membeli minuman (spending on alcohol), antara lain hilangnya kualitas hidup, semakin tingginya biaya asuransi yang dibutuhkan, biaya pengacara jika terjadi masalah hukum serta ongkos kesehatan yang ditanggung sebagai akibat kebisaan meminum alkohol (Matsubayashi \& Yoshikawa, 2018, hal. 540; McClelland \& Iselin, 2017, hal. 124; Syawi, Sondakh, \& Pengerapan, 2016, hal. 824). Adapun biaya sosial yang ditanggung juga jauh lebih tinggi, di antaranya resiko kematian prematur, kondisi kesehatan yang semakin menurun, rendahnya partisipasi kerja, tingginya resiko berperilaku konsumen, menurunnya produkstivitas dan efisiensi, imbas keluarga dan kerabat dari perilaku peminum, potensi pelanggaran hukum, biaya yang timbul untuk mengurangi ketergantungan dan lain sebagainya.

Berdasarkan pembahasan diatas maka jelas dapat ditunjukkan bahwa biaya sosial dari konsumsi minuman beralkohol jauh lebih besar dari biaya privat. Dengan kata lain, akan timbul eksternalitas negatif dari adanya konsumsi minuman beralkohol (Mahmud \& Wangkar, 2015, hal. 708). Timbulnya ekternalitas tersebut mengharuskan adanya campur tangan pemerintah untuk mengontrol besaran konsumsi sekaligus menyediakan alokasi anggaran untuk mengantisipasi efek negatif dari pemakaian alkohol. Salah satu bentuk intervensi pemerintah terhadap produk yang dikategorikan sebagai sin commodities tersebut adalah dalam bentuk pengenaan cukai terhadap setiap barang yang dijual. Cukai tersebut selanjutnya dapat digunakan oleh pemeritah untuk "membayar" ongkos sosial yang terjadi akibat adanya konsumsi barangbarang sejenis.

\subsection{Dampak Cukai Terhadap Konsumsi}

Aturan pajak atau cukai terhadap barangbarang dengan kualifikasi sin commodities selain bertujuan untuk melakukan kontrol terhadap konsumsi dan produksi, juga memiliki tujuan sosial untuk mengalokasikan anggaran sebagai konsekuensi penggunaan produk yang tidak bisa dikalkulasi secara privat. Pengenaan cukai secara ekonomi memiliki pengaruh langsung dalam bentuk kenaikan harga (Laksmana, 2008, hal . 1).

Sebuah studi dengan pendekatan analisis meta menarik untuk disimak. Gallet (2007, hal. 121) dengan menggunakan informasi dari sekitar 132 studi sebelumnya yang terhimpun dari studi kasus berbagai negara (24 negara) menyimpulkan temuan penting. Pertama, hampir semua studi menunjukkan bahwa faktor harga, pendapatan, dan pengeluaran untuk iklan minuman beralkohol memiliki kontribusi signifikan terhadap permintaan komoditi ini. Kedua, terdapat variasi hasil oleh karena adanya variasi sumber dan karakteristik data (cross-section versus time series), teknik estimasi yang dipilih serta bias lain yang tidak begitu menonjol. Ketiga, secara umum ditemukan bahwa elasititas permintaan untuk bir relatif lebih inelastis dibandingkan dengan jenis minuman beralkohol dalam bentuk wine atau minuman keras (spirits). Keempat, ditemukan bahwa elastisitas pendapatan dalam jangka pendek lebih inelastis dibandingkan dengan permintaan dalam jangka panjang (Mahmud \& Wangkar, 2015, hal. 708). Dengan kata lain, respon pendapatan terhadap konsumsi minuman berakohol baru efektif dalam jangka panjang. Kelima, terdapat bukti statistik bahwa periklanan memberikan kontribusi positif terhadap konsumsi minuman keras (Pam, Musadieq, \& Said, 2015, hal. 20). Tidak ada bukti statistik yang menunjukkan adanya perbedaan signifikan antara elastisitas advertising untuk kasus bir, wine, ataupun spirits. Temuan menunjukkan bahwa studi yang lebih baru memiliki elastisitas advertising yang relatif lebih rendah.

\subsection{Perdagangan Alkohol}

Pengenaan cukai terhadap produk minuman beralkohol membawa konsekuensi semakin mahalnya produk ini yang dijual secara resmi. 
Aturan cukai tersebut dapat memicu adanya perdagangan gelap (illicit trade). Masalah dalam perdagangan minuman beralkohol tidak hanya mendorong adanya perdagangan gelap, namun juga munculnya transaksi yang tidak tercatat (World Health Organization, 2011, hal. 33).

Secara umum terdapat dua tipe pasar minuman beralkohol, yakni yang bersifat resmi (licit) dan ilegal (illicit). Dari yang bersifat resmi, terdapat dua tipe pasar yakni yang tercatat dengan yang tidak tercatat. Penjualan alkohol resmi yang tercatat selanjutnya dilaporkan secara resmi dalam statistik komoditi secara reguler. Adapun yang tidak tercatat dan yang bersifat ilegal masih belum dapat diperkirakan secara pasti karena masuk dalam aktivitas hidden economy. Produk resmi bisa saja tidak tercatat karena dikonsumsi diluar wilayah negara produsen dan hanya dikonsumsi untuk keperluan personal. Minuman impor yang dibawa dan dikonsumsi secara personal termasuk dalam kategori ini.

Terdapat pula jenis minuman beralkohol yang sebenarnya bukan termasuk dalam perdagangan gelap namun tidak bisa tercacat. Jenis minuman tradisional beralkohol dengan produksi rumahan termasuk dalam kategori pasar minuman ini. Produksi minuman skala rumahan (homeproduced) yang tak tercatat bisa juga termasuk dalam kategori minuman yang ilegal jika terdapat ketentuan khusus yang menyebutkan bahwa minuman yang dimaksud tidak boleh diproduksi menurut aturan yang berlaku.

Selanjutnya produk minuman beralkohol yang termasuk dalam kategori illicit antara lain adalah sebagai berikut. Pertama, minuman beralkohol selundupan (smuggling) dari negara lain. Produk yang diselundupkan pada dasarnya adalah produk resmi, namun diedarkan di negara secara ilegal tanpa melalui proses administrasi bea cukai setempat untuk menghindari pembayaran pajak impor. Kedua, jenis minuman beralkohol yang sengaja dipalsukan baik dengan cara mengisi ulang atau menggunakan campuran lain selain yang telah mendapat persetujuan resmi. Ketiga, produk resmi namun dengan penggunaan cukai palsu sehingga pajaknya tidak terbayar sebagai penerimaan pemerintah yang sah. Termasuk dalam hal ini adalah penggunaan cukai bekas atau mungkin sama sekali tidak menggunakan cukai. Keempat, adalah jenis minuman beralkohol dengan ramuan tertentu yang tidak mengikuti proses produksi, petunjuk resmi dan kemasan yang dibenarkan. Di Indonesia, jenis minuman ini dikenal sebagai oplosan yang memang diracik secara asal-asalan tanpa mengikuti standar pembuatan minuman yang diatur secara resmi. Kelima, adalah jenis alkohol yang sejatinya bukan digunakan untuk keperluan konsumsi manusia, namun sengaja ditambahkan ke dalam minuman sebagai barang substitusi dari minuman beralkohol.
Bagaimanapun, disadari bahwa estimasi konsumsi alkohol yang tidak tercatat sangat mungkin jauh diatas data yang sesungguhnya. Data mengenai hal ini relatif sulit diperoleh dan pada sebagian besar kasus hanya menyandarkan pada studi yang relatif sedikit dengan sumber dari pendapat para ahli. Laporan resmi, meskipun yang dirilis oleh WHO (2011, hal. 4), ditengarai masih underestimates. Data konsumsi di negara berkembang termasuk salah satu yang sulit untuk diperoleh. Padahal informasi mengenai data per kapita konsumsi alkohol sangat diperlukan untuk mendesain kebijakan yang cocok dalam rangka pengendalian dampak buruk minuman beralkohol secara menyeluruh.

Salah satu hal menarik yang perlu diperhatikan adalah relatif banyaknya minuman beralkohol tradisional yang diproduksi secara rumahan seperti di Karagasem Bali dan Sukoharjo Jawa Tengah. Minuman sejenis ini jarang yang dapat tercatat secara resmi. Peredaran minuman beralkohol ini sangat terkait erat dengan budaya lokal setempat yang menjadikan minuman sebagai sajian dalam perayaan pernikahan, acara adat setempat, acara liburan hingga acara pemakaman. Minuman semacam ini juga sudah bisa disajikan kepada tamu. Dalam sebagian kasus, masyarakat tradisional justru ada yang percaya bahwa minuman beralkohol ini memiliki dampak positif bagi kesehatan, menambah nafsu makan, dan dapat dijadikan sebagai obat meskipun kajian ilmiah belum pernah membuktikan kebenaran asumsi tersebut.

Produksi dan konsumsi minuman beralkohol yang tidak tercatat memiliki korelasi dengan faktor ekonomi sosial secara luas. Semakin tinggi tingkat pendapatan masyarakat, maka semakin rendah level konsumsi alkohol yang tidak tercatat (World Health Organization, 2011, hal. 8). Produksi dan konsumsi minuman beralkohol ilegal tumbuh subur selama resesi ekonomi dan masa kekacauan politik, tingginya angka pengangguran, tingginya korupsi dan lemahnya penegakan hukum.

\section{METODOLOGI PENELITIAN}

Guna mengukur potensi cukai MMEA maka dilakukan estimasi tingkat konsumsi MMEA menggunakan basis data SUSENAS. Penggunaan data mikro rumah tangga dipandang sebagai cara yang efektif dan efisien untuk melakukan estimasi yang bersifat umum. Setelah dilakukan estimasi konsumsi, selanjutnya dilakukan perhitungan beban cukai yang harus terbayar akibat konsumsi minuman beralkohol.

Hasil estimasi besaran cukai nantinya dibandingkan dengan nilai penerimaan cukai aktual tahun yang sama. Selisih positif antara besaran estimasi cukai dengan penerimaan cukai sebenarnya merupakan nilai potensi penerimaan yang masih dapat ditingkatkan. Untuk mengurangi 
bias perhitungan, penelitian ini juga akan menggunakan beberapa skenario estimasi cukai sebagai alternatif jika ditemukan beberapa data yang sifatnya masih diragukan besarannya.

Secara lebih rinci, metode yang digunakan untuk menjawab pertanyaan penelitian, dapat dijelaskan sebagai berikut:

\subsection{Menghitung Potensi Penerimaan Cukai}

Potensi penerimaan cukai diestimasi berdasarkan konsumsi rumah tangga untuk minuman alkohol menurut data SUSENAS. Berdasarkan volume konsumsi yang diperoleh, selanjutnya diperkirakan jumlah cukai yang harus dibayarkan. Formula yang digunakan adalah sebagai berikut:

Penerimaan $=$ Volume $\times$ Tarif Cukai

Penerimaan adalah total perkiraan potensi cukai yang bisa diperoleh (dalam rupiah), Volume adalah jumlah konsumsi MMEA dalam liter dan Tarif Cukai adalah besaran cukai yang ditetapkan oleh pemerintah.

\subsection{Menghitung Efek Cukai}

Dampak kenaikan tarif cukai terhadap penerimaan total secara teori dilakukan dengan menghitung derivasi pertama fungsi penerimaan total terhadap perubahan cukai.

$\partial P / \partial C=f^{\prime}($ Vol $\times C u k a i)$

Dalam hal ini $\partial P / \partial C$ menunjukkan besarnya tambahan penerimaan akibat perubahan tarif cukai. Sisi kanan persamaan menunjukkan fungsi turunan pertama fungsi penerimaan cukai.

\subsection{Menghitung Elastisitas Cukai}

Elastisitas cukai yang dimaksud adalah ukuran mengenai besarnya perubahan konsumsi MMEA akibat perubahan tarif. Secara teori, perubahan tarif akan mendorong perubahan harga dan selanjutnya akan memicu perubahan konsumsi. Formula untuk menghitung elastisitas cukai adalah sebagai berikut:

$\alpha=\partial Q / \partial C \times C / Q$

Dalam hal ini $\alpha$ menunjukkan elastisitas cukai, $Q$ menunjukkan besarnya konsumsi MMEA dan $C$ adalah besarnya konsumsi. Setelah elastisitas ditentukan, maka langkah selanjutnya adalah memperkirakan dampak kuantitatif perubahan besaran tarif terhadap volume konsumsi. Besar elastisitas untuk produk MMEA dapat dihitung berdasarkan estimasi regresi atau bisa menggunakan referensi dari hasil riset sebelumnya, khususnya yang terkait dengan perilaku konsumen dalam mengonsumsi MMEA.

\section{HASIL PENELITIAN}

Pada bagian ini akan dibahas hasil dari penelitian yang terbagi atas tiga sub seksi, yakni (1) perhitungan potensi cukai; (2) perhitungan efek kenaikan cukai alkohol serta; (3) kasus penindakan minuman beralkohol yang selama ini telah dilaksanakan. Perhitungan potensi cukai dari alkohol pada dasarnya didasarkan pada analisis data sekunder yang terlapor oleh konsumen.

\subsection{Potensi Cukai MMEA}

Hasil penelitian akan diurai sesuai dengan tujuan serta metode perhitungan yang digunakan. Beberapa data hasil penelitian sebelumnya juga digunakan dalam penelitian ini, antara lain, survei MMEA yang pernah dilakukan oleh Tim Peneliti FEB UGM (P2EB FEB UGM, 2016, hal. 10). Hasil survei tersebut salah satunya adalah mengurai distribusi MMEA menurut Golongan A, Golongan B maupun Golongan C.

Perhitungan potensi cukai ini dilakukan dengan beberapa asumsi. Pertama, data konsumsi MMEA yang digunakan adalah berbasis pada hasil SUSENAS 2017. Kedua, total konsumsi MMEA diasumsikan dapat diidentifikasi sebagai Golongan A (kadar alkohol dibawah 5\%); Golongan B (kadar alkohol antara 5\% - 20\%) dan Golongan C (kadar alkohol diatas 20\%). Ketiga, tarif cukai MMEA yang diacu adalah PMK 158/PMK 010/2018 tentang tarif cukai etil alkohol (Menteri Keuangan Republik Indonesia, 2018, hal. 10-11).

Berdasarkan hasil survei SUSENAS 2017 dapat ditunjukkan bahwa total konsumsi MMEA di Indonesia kurang lebih sekitar 500 juta botol dalam satu tahun (Badan Pusat Statistik, 2018, hal. 5). Angka ini selanjutnya dibulatkan untuk tujuan penyederhanaan perhitungan. Selanjutnya, berdasarkan survei lapangan Tim FEB UGM pada tahun 2016, distribusi MMEA terbanyak adalah berupa MMEA Golongan A (sekitar 50\%), Golongan B (sekitar 40\%) dan Golongan C (sekitar 10\%) (P2EB FEB UGM, 2016, hal. 10).

Langkah selanjutnya adalah menaksir perkiraan perolehan penerimaan negara dari cukai MMEA dengan data sebagaimana diurai diatas. Hasil estimasi kasar menunjukkan bahwa potensi penerimaan cukai sebesar Rp 8,89 Triliun. Angka potensi penerimaan ini mungkin relatif masih kasar karena beberapa perhitungan tarif untuk Golongan MMEA tertentu hanya dihitung nilai batas rendahnya. Sebagai contoh, secara skematis, struktur tarif MMEA Golongan B adalah Rp 33.000 untuk MMEA Indonesia dan $\mathrm{Rp} 44.000$ untuk MMEA impor. Maka digunakan tarif impor sebesar Rp 33.000. Hal yang sama dilakukan untuk MMEA Golongan $\mathrm{C}$ yang memiliki dua skema tarif. 
Sementara itu, untuk MMEA Golongan A, karena memiliki satu skema, maka angka tersebut tidak terlalu dapat dipermasalahkan.

Tabel 4.1

Potensi Penerimaan Cukai MMEA: Skenario 1

\begin{tabular}{|c|c|c|c|c|c|c|}
\hline No. & Golongan & Porsi & Volume & Liter & Tarif (Rp) & Potensi Cukai (Rp) \\
\hline 1 & $\mathrm{~A}$ & $50 \%$ & 248.711 .000 & 155.200 .000 & 15.000 & 2.325 .000 .002 .604 \\
\hline 2 & $\mathrm{~B}$ & $40 \%$ & 198.000 .000 & 124.049 .000 & 33.000 & 4.092 .000 .004 .583 \\
\hline 3 & $\mathrm{C}$ & $10 \%$ & 54.255 .000 & 31.638 .000 & 80.000 & 2.480 .000 .002 .778 \\
\hline & \multicolumn{2}{|c|}{ Total Konsumsi } & $\mathbf{5 0 1 . 4 3 3 . 0 0 0}$ & \multicolumn{2}{|c|}{ Total Penerimaan } & $\mathbf{8 . 8 9 7 . 0 0 0 . 0 0 9 . 9 6 5}$ \\
\hline
\end{tabular}

Sumber: Kalkulasi penulis

Hasil estimasi potensi penerimaan cukai MMEA sebagaimana tersaji dalam Tabel4.1 diatas menyajikan perhitungan dengan asumsi penggunaan tarif cukai terendah. Perlu disampaikan kembali bahwa angka volume konsumsi dalam botol merupakan angka penghalusan. Demikian halnya dengan porsi MMEA pada setiap golongan.
Perhitungan menunjukkan bahwa dengan skenario bawah, diperoleh estimasi penerimaan cukai MMEA sebesar Rp 8,8 Triliun. Angka ini masih lebih tinggi dibandingkan dengan realisasi penerimaan MMEA yang "hanya" mencapai Rp 5,86 Triliun per 14 Desember 2018. Angka potensi ini juga jauh lebih besar dibandingkan dengan angka target penerimaan cukai MMEA yang diperkirakan mencapai kisaran Rp 6,5 Triliun.

Tabel 4.2

Potensi Penerimaan Cukai MMEA: Skenario 2

\begin{tabular}{|c|c|c|c|c|c|c|}
\hline No. & Golongan & Porsi & Volume & Liter & Tarif (Rp) & Potensi Cukai (Rp) \\
\hline 1 & A & $50.0 \%$ & 248.711 .000 & 155.200 .000 & 15.000 & 2.325 .000 .002 .604 \\
\hline 2 & B & $40.0 \%$ & 198.000 .000 & 124.049 .000 & 38.500 & 4.774 .000 .005 .347 \\
\hline 3 & C & $10.0 \%$ & 54.255 .000 & 31.638 .000 & 109.500 & 3.394 .500 .003 .802 \\
\hline & \multicolumn{2}{|c|}{ Total Konsumsi } & $\mathbf{5 0 1 . 4 3 3 . 0 0 0}$ & $\mathbf{5 0 1 . 4 3 3 . 0 0 0}$ & $\mathbf{1 0 . 4 9 3 . 5 0 0 . 0 1 1 . 7 5 3}$ \\
\hline
\end{tabular}

Sumber: Kalkulasi penulis

Hasil perhitungan potensi cukai MMEA dalam Tabel 4.2 diperoleh dengan asumsi perhitungan tarif cukai rata-rata untuk Golongan B dan Golongan C. Tarif rata-rata untuk Golongan B sebesar Rp 38.500 per liter; sementara itu tarif rata-rata MMEA Golongan C adalah sebesar $\mathrm{Rp}$ 109.500 per liter. Dengan formasi tarif yang sedemikian, maka diperkirakan perolehan cukai dari MMEA adalah sebesar Rp 10, 4 Triliun.

Estimasi penerimaan cukai MMEA sebesar Rp 10 Triliun lebih mungkin terlalu over-estimates. Perhitungan tersebut secara tidak langsung mengasumsikan bahwa produk MMEA lokal dan MMEA impor cukup berimbang. Meskipun hal tersebut bisa saja terjadi, namun berdasarkan data produksi, produk MMEA impor sampai saat ini relatif lebih sedikit dibandingkan dengan produk MMEA buatan dalam negeri.

Untuk memperoleh hasil estimasi yang lebih moderat, skenario lain disusun. Pertama, konsumsi MMEA Golongan A dipertahankan tetap. Kedua, konsumsi MMEA Golongan B dipecah dengan asumsi bahwa 70\% konsumsi MMEA Golongan B merupakan produk nasional. Sementara itu sisanya (30\%) konsumsi MMEA Golongan B merupakan produk impor.

Hal yang sama juga diterapkan untuk MMEA Golongan C. Diasumsikan bahwa 70\% MMEA Golongan C merupakan produk nasional, sedangkan sisanya, sebanyak 30\% merupakan produk impor.

Selanjutnya, tarif untuk masing-masing golongan disesuaikan dengan ketentuan tarif yang 
berlaku. Tarif cukai MMEA untuk produk impor secara signifikan berbeda dengan tarif cukai MMEA lokal/nasional untuk golongan yang sama. Hasil simulasi perhitungan potensi penerimaan cukai dengan skenario moderat dapat diperhatikan

Tabel 4.3

Potensi Penerimaan Cukai MMEA: Skenario 3

\begin{tabular}{|c|c|c|c|r|r|r|}
\hline No. & Golongan & Porsi & \multicolumn{1}{c|}{ Volume } & \multicolumn{1}{c|}{ Liter } & Tarif (Rp) & Potensi Cukai (Rp) \\
\hline 1 & $\mathrm{~A}$ & $50 \%$ & 248.711 .000 & 155.000 .000 & 15.000 & 2.325 .000 .002 .604 \\
\hline \multirow{2}{*}{2} & \multirow{2}{*}{$\mathrm{B}$} & $28 \%$ & 138.997 .000 & 86.800 .000 & 33.000 & 2.864 .400 .003 .208 \\
\cline { 3 - 7 } & & $12 \%$ & 59.570 .000 & 37.200 .000 & 44.000 & $1.636,800.001 .833$ \\
\hline \multirow{2}{*}{3} & $\mathrm{C}$ & $7 \%$ & 35.908 .000 & 21.700 .000 & 80.000 & 1.736 .000 .001 .944 \\
\cline { 3 - 7 } & & $3 \%$ & 16.246 .000 & 9.300 .000 & 139.000 & 1.292 .700 .001 .448 \\
\hline
\end{tabular}

Sumber: Kalkulasi penulis

Hasil perhitungan potensi penerimaan cukai MMEA dengan menggunakan skenario moderat diperoleh taksiran sebesar Rp 9,85 Triliun. Perbedaan hasil taksiran penerimaan cukai antara skenario pertama, kedua dan ketiga adalah terletak pada asumsi mengenai distribusi konsumsi MMEA lokal dengan kosumsi MMEA impor.

Berdasarkan beberapa skenario yang dibuat, diperkirakan nilai potensi cukai MMEA yang seharusnya dapat diterima oleh negara adalah berkisar antara Rp 8 Triliun - Rp 10 Triliun. Ratarata potensi penerimaan cukai MMEA adalah sebesar Rp 9,74 Triliun.

Angka potensi penerimaan cukai MMEA ini jauh lebih besar dibandingkan dengan realisasi dalam Tabel 4.3 pada halaman berikut. Hasil perhitungan menunjukkan bahwa potensi cukai MMEA skenario terakhir berada di antara skenario pertama dan kedua. penerimaan cukai MMEA sebesar Rp 5,86 Triliun pada tahun 2018 atau target penerimaan cukai MMEA sebesar Rp 6,5 Triliun.

\subsection{Efek Kenaikan Cukai}

Setelah dilakukan perhitungan potensi cukai dengan melakukan skenario terhadap distribusi konsumsi MMEA, maka langkah penelitian selanjutnya adalah mengestimasi sensitivitas kenaikan tarif cukai terhadap total penerimaan. Distribusi konsumsi MMEA yang digunakan adalah sebagaimana yang disajikan dalam Tabel 4.3.

Dengan menggunakan skenario kenaikan tarif cukai MMEA sebesar Rp 1.000 untuk masingmasing skema, selanjutnya dihitung dampak persentase perubahan penerimaan negara akibat perubahan tarif cukai.

\section{Gambar 4.1}

\section{Simulasi Efek Kenaikan Tarif Terhadap Penerimaan Cukai MMEA}

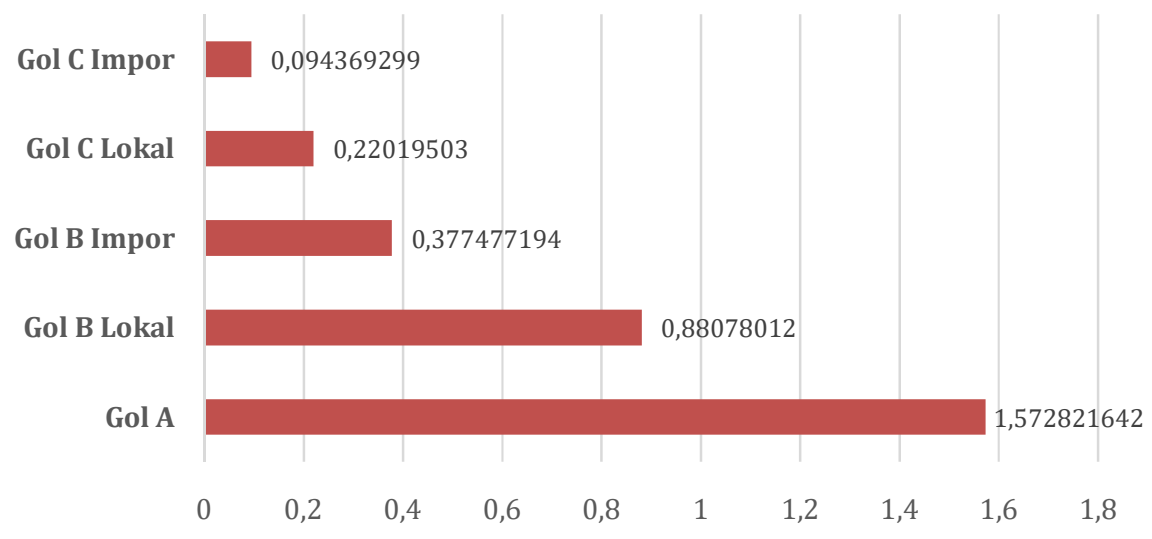

Sumber: Kalkulasi penulis 
Hasil perhitungan menunjukkan bahwa jika dilakukan kenaikan tarif sebesar $\mathrm{Rp}$ 1.000, maka Golongan MMEA yang paling pesat meningkat adalah yang berasal dari Golongan A. Dengan kenaikan tarif sebesar Rp 1.000, maka persentase kenaikan cukai MMEA diperkirakan sebesar 1,57 persen. Selanjutnya jika kenaikan terjadi untuk Golongan B lokal, maka diperkirakan terjadi kenaikan penerimaan cukai sebesar 0,88 persen.

Selanjutnya dapat diperiksa bahwa kenaikan tarif sebesar $\mathrm{Rp} 1.000$ tidak terlalu banyak menyumbang terhadap kenaikan cukai untuk kasus MMEA Golongan C Impor. Hasil simulasi menunjukkan bahwa kenaikan penerimaan cukai yang diperoleh hanya mencapai sekitar 0,09 persen.

\subsection{Penindakan}

Dengan memperhatikan hasil temuan dan simulasi perhitungan potensi penerimaan negara dari cukai MMEA 2016 ini maka dapat dikatakan masih terdapat peluang untuk meningkatkan penerimaan negara dari sektor ini. Beberapa langkah tentunya dapat diambil oleh pemerintah untuk meningkatkan penerimaan, salah satunya dengan peningkatan pengawasan terhadap peredaran produk MMEA ilegal yang tidak menggunakan pita cukai sepeti penyelundupan MMEA dari luar negeri. Modus penyelundupan barang MMEA ilegal semakin canggih, namun proses penindakan terhadap aktivitas melanggar aturan ini wajib untuk tetap digalakkan.

\section{Gambar 4.2 \\ Penindakan Kasus MMEA di Indonesia}

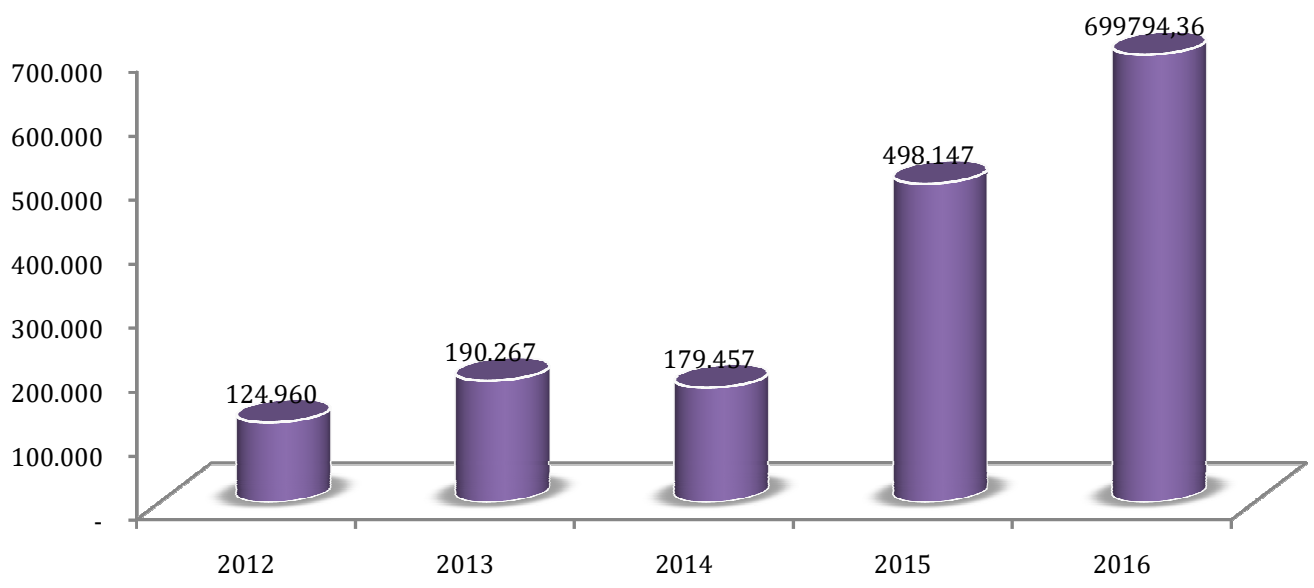

Sumber: Bea dan Cukai dalam laporan survei P2EB (2016, hal. 20)

Terdapat kecenderungan bahwa volume penindakan terhadap peredaran MMEA ilegal mengalami peningkatan dari tahun ke tahun. Pada akhir 2016 diproyeksikan bahwa volume penindakan akan berkisar 699.794 liter. Meskipun volume penindakan MMEA ini masih relatif kecil dibandingkan dengan konsumsi MMEA secara total, namun jika dikalikan dengan potensi penerimaan tarif yang "hilang" tentu bukan suatu angka yang kecil.

Penindakan terhadap peredaran MMEA ilegal ini dapat menjadi salah satu sarana yang efektif untuk meningkatkan potensi penerimaan negara. Namun demikian, langkah ini perlu juga diiringi dengan pendekatan persuasif kepada masyarakat dalam mengonsumsi produk MMEA. Sebagai produk dengan kategori sin commodity, pengenaan cukai pada hakikatnya untuk mengendalikan peredaran produk tersebut secara meluas di masyarakat. Pemerintah wajib mengendalikan peredaran MMEA sesuai dengan amanat peraturan formal (undang-undang, perda, dan lain sebagainya) maupun tata aturan informal yang beredar secara kultural di masyarakat.

\section{KESIMPULAN}

Hasil penelitian mengenai optimalisasi penerimaan cukai MMEA di Indonesia ini menghasilkan beberapa temuan penting. Pertama, dengan menggunakan pendekatan konsumsi dapat ditelusuri bahwa penerimaan negara dari cukai MMEA selama ini relatif belum optimal. Hal ini dapat dievaluasi berdasarkan perbedaan antara potensi dengan cukai aktual MMEA yang dikumpulkan. Kedua, penerimaan cukai MMEA pada dasarnya masih sangat terbuka untuk ditingkatkan karena masih terdapat sekitar Rp 3 4 Triliun potensi penerimaan cukai MMEA yang masih bisa digali.

Ketiga, berdasarkan simulasi efek cukai, dapat ditemukan bahwa MMEA Golongan A (dengan 
kadar alkohol yang paling rendah) sangat sensitif terhadap kenaikan tarif. Kenaikan tarif dengan porsi yang relatif kecil, akan meningkatkan pendapatan cukai MMEA secara cukup signifikan. Sementara itu, kenaikan cukai untuk MMEA Golongan $\mathrm{C}$ relatif memberikan efek kenaikan cukai yang lebih kecil.

\section{IMPLIKASI DAN KETERBATASAN}

Berdasarkan temuan dalam penelitian ini, maka dapat ditarik beberapa hal penting. Pertama, adanya gap yang cukup besar antara potensi cukai MMEA dengan penerimaan cukai MMEA mengindikasikan adanya un-recorded alcohol yang cukup besar di Indonesia. Masih banyak MMEA yang tidak tersentuh oleh cukai. Sebagian besar MMEA dimaksud adalah MMEA tradisional yang peredarannya masih belum sepenuhnya terdeteksi.

Implikasi lain adalah bahwa kebijakan penentuan tarif cukai MMEA harus mempertimbangkan bahwa MMEA merupakan komoditi yang masuk dalam kategori sincommodity. Jika tujuan utama cukai adalah pengendalian konsumsi, maka fokus kenaikan tarif mungkin akan lebih efektif untuk diterapkan pada MMEA Golongan A. Strategi ini tidak hanya akan mendongkrak penerimaan secara lebih besar, namun dipercaya akan menurunkan konsumsi minuman keras secara signifikan.

Beberapa kelemahan studi ini dapat diurai sebagai berikut. Pertama, basis data konsumsi yang digunakan relatif beragam dalam hal satuan ukur. Penyesuaian perhitungan pada dasarnya lebih banyak bersifat aproksimatif. Namun demikian, temuan yang dihasilkan dalam penelitian tidak terlalu banyak menyimpang dari "fakta" MMEA yang sebenarnya. Ke depan, studi potensi cukai mungkin perlu diperkaya dengan data berbasis produksi. Kedua, elastisitas cukai terhadap konsumsi tidak dikupas secara detail. Jika data yang dibutuhkan tersedia, maka tidak menutup kemungkinan bahwa hasil kajian semacam ini dapat dilakukan.

\section{PENGHARGAAN}

Penulis mengucapkan terima kasih terhadap Jurusan Ilmu Ekonomi Pembangunan - Fakultas Ekonomi dan Bisnis Universitas Trunojoyo Madura yang telah memfasilitasi penelitian ini melalui pendanaan yang sifatnya kompetitif melalui Skema Penelitian Unggulan Jurusan tahun 2019. Penulis juga menyampaikan penghargaan yang sebesarbesarnya kepada pihak yang turut membantu terselesainya naskah artikel ini.

\section{REFERENSI}

Badan Pusat Statistik. (2018). Survei sosial ekonomi nasional 2017. Jakarta: Badan Pusat Statistik Indonesia.

Chandra, E. M., \& Gufraeni, R. (2009). Kajian ekstensifikasi barang kena cukai pada minuman ringan berkarbonasi. Jurnal Ilmu Administrasi dan Organisasi, 16(3), 170-179.

Chen, W. Y., Chen, Y. Y., Liu, H. H., Kuo, P. H., \& Huang, M. C. (2018). The possible mediating effect of alcohol dependence on the relationship between adverse childhood experiences and attempted suicide. Elsevier, 7(3), 9-15.

Chisholm, D., Moro, D., Bertram, M., Pretorius, C., Gmel, G., Shield, K., \& Rehm, J. (2018). Are the "best buys" for alcohol control still valid? an update on the comparative cost-effectiveness of alcohol control strategies at the global level. Journal of Studies on Alcohol and Drugs, 79(4), 514-522.

Direktorat Jenderal Anggaran. (2017). Informasi anggaran 2018. Jakarta: Direktorat Jenderal Anggaran.

Gallet, C. A. (2007). The demand for alcohol: a meta analysis of elasticities. The Australian Journal of Agricultural and Resources Economics, 51(2), 121135.

Haas, A. L., Wickham, R. E., McKenna, K., Morimoto, E., \& Brown, L. M. (2018). Evaluating the effectiveness of a medical amnesty policy change on college students' alcohol consumption, physiological consequences, and helping behaviors. Journal of Studies on Alcohol and Drug, 79(4), 523531.

Hessari, N. M., Knai, C., Morvan, K. G., Petticrew , M., \& Landreat, M. G. (2018). Stakeholder framing of advertising legislation: an analysis of media and parliamentary representations of the loi évin in the United Kingdom. Journal of Studies on Alcohol and Drugs, 79(4), 532-538.

IAS. (2013). Economic impact of alcohol. London: Institute of Alcohol Studies.

Jernigan, D., \& Waters, H. (2009). The potential benefits of alcohol excise tax increases in Maryland. Washington: Center on Alcohol Marketing and Youth.

Kementerian Keuangan Republik Indonesia. (2018). Tarif cukai etil alkohol, minuman yang mengandung etil alkohol dan konsentrat mengandung etil alkohol. Jakarta: Kementerian Keuangan Republik Indonesia. 
140

Laksmana, R. (2008). Faktor-faktor yang mempengaruhi tingkat produksi etil alkohol dan minuman mengandung etil alkohol di Indonesia (2003-2007), halaman 2-15. Diakses Januari 2008, dari Laporan Kantor Pusat Ditjen Bea dan Cukai.

McClelland, R., \& Iselin, J. (2017). Do alcohol excise taxes reduce motor vehicle fatalities? evidence from two illinois tax increase. urban institute, tax policy center. Washington: Urban Institute.

Mahmud, L., \& Wangkar, A. (2015). Evaluasi prosedur pemungutan cukai minuman beralkohol buatan dalam negeri pada Kantor Pengawasan dan Pelayanan Bea dan Cukai Tipe Madya Pabean C Manado. Jurnal EMBA, 3(1), 707-715.

Matsubayashi, T., \& Yoshikawa, K. (2018). Minimum legal drinking age and youth health: evidence from Japan. Journal of Studies on Alcohol and Drugs, 79(4), 539-546.
Pam, D. R., Musadieq, M. A., \& Said, A. (2015). Evaluasi kebijakan pengawasan pelekatan pita cukai pada minuman mengandung etil alkohol (mmea) buatan dalam negeri (Studi pada Kantor Pengawasan dan Pelayanan (KPPBC) Tipe Madya Cukai Malang). Jurnal Perpajakan (JEJAK), 1(1), 1-8.

P2EB FEB UGM. (2016). Survei MMEA tradisional di Indonesia. Yogyakarta: FEB UGM.

Syawie, F. A., Sondakh, J. J., \& Pangerapan, S. (2016). Evaluasi pelaksanaan dan pemungutan cukai minuman beralkohol buatan dalam negeri berdasarkan per-01/bc/2014 dan per-24/bc/2015 pada Kantor Pengawasan dan Pelayanan Bea dan Cukai Tipe Pabean C Manado. Jurnal EMBA, 4(4), 824-833.

World Health Organization. (2011). Global status report on alcohol and health. Geneva: World Health Organization. 


\section{LAMPIRAN}

Tabel A.

Potensi dan Target Penerimaan Cukai MMEA

\begin{tabular}{|l|c|c|}
\hline & Skenario 1 & Skenario 2 \\
\hline Volume (botol) & 501.433 .977 & 501.433 .977 \\
\hline Asumsi tarif & $\begin{array}{c}\text { Seluruhnya Menggunakan } \\
\text { Tarif Domestik Untuk Semua } \\
\text { Golongan MMEA }\end{array}$ & $\begin{array}{c}\text { Menggunakan Tarif Domestik } \\
\text { dan Impor Untuk Golongan B } \\
\text { dan Golongan C }\end{array}$ \\
\hline Tarif acuan & 13.000 & 13.000 \\
Golongan A (Rp/liter) & 33.000 & $33.000 / 44.000$ \\
Golongan B (Rp/liter) & 80.000 & $80.000 / 139.000$ \\
Golongan C (Rp/liter) & $\mathbf{8 . 7 5 6 . 3 1 4 . 8 9 5 . 6 8 6}$ & $\mathbf{9 . 7 5 3 . 9 5 7 . 9 0 8 . 0 4 3}$ \\
\hline Potensi Penerimaan Cukai (Rp) & $\mathbf{6 . 4 5 0 . 0 0 0 . 0 0 0 . 0 0 0}$ \\
\hline Target Penerimaan 2016 (Rp)* & $\mathbf{2 . 3 0 6 . 3 1 4 . 8 9 5 . 6 8 6}$ & $\mathbf{3 . 3 0 3 . 9 5 7 . 9 0 8 . 0 4 3}$ \\
\hline Selisih Potensi - Target & \multicolumn{2}{|c|}{} \\
\hline
\end{tabular}

